\title{
Corporate Governance in Shipping Logistics Industry: A Practitioner's Perspectives
}

\author{
Simon S.M Yuen, Ph.D \\ School of Professional Education and Executive Development \\ The Hong Kong Polytechnic University \\ Annie H.C. Ko, Ph.D \\ School of Professional Education and Executive Development \\ The Hong Kong Polytechnic University
}

\begin{abstract}
Recently, the international liner shipping companies Hanjin bankruptcy incident more fully prove the importance of corporate governance in shipping logistics industry. Good practice of CG implementation not only well monitor and alert the company performance (i.e. profit warning), but also enhance business \& management efficiency and competitive advantages. Although corporate governance is vital to achieve the company's best practices, it only has limited numbers of research and literature in related discipline. This study aims to investigate the governance compliance level; the strengths and weaknesses of the industry in terms of governance practices in Hong Kong maritime logistics industry. An in-depth semi-structured interview with five practitioners was conducted to identify the importance and values of CG practices. The study confirmed that the CG practices not only improve her business performance, but also enhance company's sustainable development in different aspects: (1) Rights of Shareholders; (2) Equitable Treatment of Shareholders; (3) Role of Stakeholders; (4) Disclosure and Transparency, and (5) Board Responsibilities. In general, this study arouse the awareness of CG in shipping logistics industry in Hong Kong and Asia; contributes to the both managerial understanding and enrich academic knowledge for further studies of other related fields such as freight forwarding and aviation sector.
\end{abstract}

Keywords: Corporate Governance, Shipping, Logistics Industry, Hong Kong.

JEL Classification: G34

\section{Introduction}

Globalization, logistics and supply chain integration as well as the consequent expansion of the shipping industry have refined the functional role of different aspects of supply chains, such as shipping, ports \& freight distribution (Song and Panayides, 2012). The dramatic increase in world trade in the past decades has restructured the global maritime industry bringing about new development, de-regulation, liberalization and increase competition. In order to maintain her business competitiveness and sustainable business practices, Corporate Governance (CG) is one of the most important criteria for leading shipping logistics companies in Hong Kong and worldwide.

Previous researches mainly focus on the financial performances of the listed companies in the shipping logistics industry; however, a company with good financial performance does not necessarily mean it practices good corporate governance (Andreou et al., 2014).

In terms of promoting good governance, Hong Kong is one of the pioneers in the world; The Hong Kong Exchange issued the code of good governance (the Code) in 1989; which was the second market to issue such code. Since then improvements and modifications are made from time to time.

In Asia, corporate governance studies focuses on executive compensation and ownership structure (Firth, Fung \&Rui, 2007; Ko \& So, 2012). Cheung (2012) and Ko et al. (2016) are the recent studies on corporate governance of Hong Kong listed companies. The former one used a scorecard to examine the overall corporate governance performance of 121 listed companies in Hong Kong, while the latter one studies the governance level of the logistics and shipping industry in Hong Kong between 2003 and 2014. 
In this study, we have interviewed five practitioners who have been working in the industry. Five corporate governance aspects, namely Rights of Shareholders, Equitable Treatment of Shareholders, Roles of Stakeholders, Disclosure and Transparency, and Board Responsibilities, are adopted for the instrument (Cheung, 2012; Ko et al., 2016; OECD, 2004).

\section{Literature Review}

\subsection{Corporate Governance in Shipping Logistics industry}

Globalization and technological advancements led more maritime, shipping \& logistics companies rely on capital markets to finance investment opportunities (Syriopoulos and Theotokas, 2007) such as Initial Public Offerings (IPOs) (Grammenos and Papapostolou, 2012). The listed shipping and logistics corporates not only appreciate the goodwill from the quality of corporate governance $(\mathrm{CG})$ system, but also mitigate the inherent uncertainty and volatility of the shipping freight markets (Song and Panayides, 2012).

Recently, the international liner shipping companies Hanjin bankruptcy incident more fully prove the importance of corporate governance in shipping logistics industry (Wei, 2017). Good practice of CG implementation not only well monitor and alert the company performance (i.e. profit warning), but also enhance business \& management efficiency and competitive advantages.

With a prime competition and international integration of capital market in shipping logistics sector, corporate governance (CG) are becoming a key factor to enhance their operational efficiency and financial performance. For the literature of CG in shipping logistics industry, a little emphasis has been given in past years (Koufopoulos et al. 2010).

Randoy, Down and Jensen (2003) investigated the financial performance effect of main corporate governance mechanisms. Empirical study was conducted to assess the effect of main corporate governance mechanisms on the financial performance of maritime companies (Syriopoulos and Tsatsaronis, 2011). Also, Tsionas, Merikas and Merika (2012) identified relationship between concentrated ownership and corporate performance.

Giannakopoulou et al. (2016) provided a detail review about the CG mechanism and assessing the implications of CG structure in operational and financial performance. The study highlighted the important issue related to CG in highly dynamic, purely international and family owned industry. In general, previous CG studies are focused in different perspectives, however, it remains still understudied.

As mentioned, corporate governance is vital to achieve the company's best practices, it only has limited numbers of research and literature in related discipline. Previous studies examining corporate governance in shipping logistics firms are leave many questions and empirical issues un-answered, especially when it comes to the relationship of corporate governance practices with financial management decisions pertaining to earnings management, investments and firm performance (Song and Panayides, 2012). Moreover, previous studies in the shipping \& logistics sector have conducted in particular zones, such as European region and Southeast Asia (Koufopoulos et al., 2010;Tuan, 2013;Randoy et al., 2003; Syriopoulos and Tsatsaronis, 2011). On these grounds, this study expects to fill the research gap though "review, identify and examine" the good corporate governance practices in Hong Kong shipping logistics industry.

\subsection{Elements of Individual Corporate Governance}

In Western world, the elements of individual corporate governance have been studied, and ownership structure is one of the proxies for governance. Corporate value is a function of the equity ownership structure (Ko et al., 2016; McConnell \&Servase, 1990; Morck, Shleifer \&Vishny, 1988). By measuring board composition, governance can be quantified (Hermalin \& Weisbach, 1991). Agency problems between shareholders and management can be mitigated, such as inside board members own more shares in the firm, therefore, those with more stocks is a good governance mechanism during corporate buyouts (Lee, Rosenstein, Rangan, \& Davidson, 1992).

Bhagat and Black (2002) found that board with high independent level did not necessarily lead to better governance. They concluded that when firms try to solve business problems by hiring more independent directors, these firms tend to be worse off. Yermack (1996) found that small board leads to stronger CEO performance incentives, in turn good corporate governance. Karuna (2007) concluded that industry competition is essential element to good governance, who found that pay performance sensitivity are related positively to competitions. Therefore, management has to do better to obtain more pay. 
In Eastern market, studies on individual governance elements are limited. Some of the studies were conducted on cases in Hong Kong, such as Chen and Jaggi (2000), who measured the governance level of firm by using ownership structure and board composition. They found that higher ratio of independent non-executive directors to the total number of directors lead to good governance. Leung and Horwitz (2004) concluded that high board ownership correlates with poor disclosure and transparency. Ko and Chan (2014) studied how concentrated ownership structures affect positive association between pay-performance sensitivities and industry competitions, and they found that competition leads to better governance only when the firm is not own by family.

\subsection{Corporate Governance Ratings}

Three major commercial rating services in the U.S. are Institutional Shareholder Services' Corporate Governance Quotient (CGQ), Governance Metrics International (GMI), and The Corporate Library's TCL rating (TCL). They are designed for evaluating the level of corporate governance of the listed companies, which are varied in terms of study approach, sample size, and focus (Ko et al., 2016).

The CGQ rating, according to Institutional Shareholder Services (2003), are prepared based on data collected from public findings and company survey consists of eight categories, namely board of directors, audit, charter, and bylaw provisions, anti-takeover provisions, executive and director compensation, progressive practices, ownership and director education.

While GMI rating, measures corporate governance mechanisms of listed companies, for examples, firms' compliance with securities regulations and corporate governance codes, compensations, board membership, board structure and takeover defenses (Daines, Gow \& Larcker, 2010; Ko et al. 2016). The scoring system is complicated and the results support that in the long run, companies emphasized corporate governance and transparency can lower the costs and enhance economic performance.

However, comparing with the above two ratings, which are quantitative, the TCL is a rating in qualitative analysis. The ratings of TCL require subjective judgment and expertise (Ko et al., 2016). The analysis is assessed based on analysts' experience and judgments. Four major areas include company's board and succession planning, CEO compensation practices, takeover defenses, and board-level accounting concerns.

La Porta, Lopez-de-Silanes, Schleifer, and Vishny (1998) combined individual governance elements to form a comprehensive index, which included legal rules pertaining to the rights of investors, voting powers, ease of participation in corporate voting, the quality of enforcement of these rules, and legal protection against expropriation by management of shareholder protections around the world. Gompers, Ishii, and Metrick (2003) invented a governance score (G-score), which consists of 24 governance rules. They are anti-greenmail, blank check, business combination laws, bylaw and charter, cash-out laws, classified board, compensation plans, contracts, control-share acquisition laws, cumulative voting, directors' duties, fair-price, golden parachutes, director indemnification, director liability, pension parachutes, poison pills, secret ballot, severance, silver parachutes, special meeting, supermajority, unequal voting, written consent.

Cheung (2012) designed a corporate governance index (CGI) to measure the performance of overall corporate governance of listed companies in Hong Kong. Also, Ko et al. (2016) conducted a study to examine the trends of the corporate governance performance of logistics and shipping listed companies in Hong Kong between 2003 and 2014, using the instrument consisted of five aspects, based on the Principles of Corporate Governance (OECD, 2004) and Report on the HKIoD Corporate Governance Score-card (Cheung, 2012) with modification. They are (A) Rights of Shareholders, (B) Equitable Treatment of Shareholders, (C) Role of Stakeholders, (D) Disclosure and Transparency, and (E) Board Responsibilities.

\section{Research Methodology}

In this study, semi-structured interviews have been carried out to collect data from the respondents. The use of interviews for business research has the following advantages. First, interview is a practical and efficient way of collecting data which cannot be found in the published format, such as journal articles, books, magazines, newspapers, etc. In addition, reasons like study on people's experience from their points of view, using interview as the method could gather specific and additional points which are insightful (Cooper \& Schindler, 2003; Eriksson \&Kovalainen, 2016; Miles \& Huberman, 1994; Myers, 2013; Naslund, 2002).

Among various types of interview, semi-structured interview is chosen as the method to be employed. There are three types of qualitative interviews, namely structured and standardized interview, guided and semi-structured interview, and unstructured, informal, open and narrative interviews (Cooper \& Schindler, 2003; Bryman \& Bell, 116 
2015; Eriksson \& Kovalainen, 2016). Structured and standardized interview usually ask standardized questions from the respondents, which are mostly "what" questions. The disadvantage of this type of interview is that it is too restrictive to be used for the main source of data, and less flexibility for interviewer responding to the particular concerns of the interviewees (Cooper \& Schindler, 2003; Bryman \& Bell, 2015; Eriksson \&Kovalainen, 2016; Mangan, Lalwani\& Gardner, 2004; Myers, 2013; Naslund, 2002).

For asking "what" and "how" questions, both guided and semi-structured interview, and unstructured, informal, open and narrative interviews can be employed. However, the latter is not suitable for the study, as this type of interview provides too much freedom for interviewees to respond, which may make the direction of the questions' focus be distracted (Cooper \& Schindler, 2003; Bryman \& Bell, 2015; Eriksson \&Kovalainen, 2016; Myers, 2013).

Guided and semi-structured interview, is another way to ask "what" and "how" questions. The interviewer can take a pre-design outline of topics and issues, with a possibility and flexibility in questions order and wording, to adopt in each interview (Cooper \& Schindler, 2003; Bryman \& Bell, 2015; Eriksson \&Kovalainen, 2016; Myers, 2013; Naslund, 2002). After comparing the types of interview above, guided and semi-structured interview is more appropriate in this study. And this type is employed as method for collecting data from respondents.

The instrument is mainly based on the study from Ko, Yuen, and Yung (2016), which was a rating instrument constructed with reference on the Principles of Corporate Governance (OECD, 2004) and the Report on the HKIoD Corporate Governance Scorecard (Cheung, 2012). In the study of Ko, Yuen, and Yung (2016), some questions were added on corporate governance mechanism which was not required in the regulations in order to examine the companies' initiatives in practicing corporate governance. The instrument contains five aspects, which are (1) Rights of Shareholders; (2) Equitable Treatment of Shareholders; (3) Role of Stakeholders; (4) Disclosure and Transparency, and (5) Board Responsibilities. There are 29 interview questions in total covering those five areas.

\section{Data Collection}

The semi-structured interviews were carried out between February and July 2016. Total of five practitioners were invited to share their views on corporate governance in logistics and shipping industry of Hong Kong. The interviewees, four of them were middle to senior management of the local listed companies in logistics and shipping industry. While one of them are experienced practitioner and chairman of one of the professional associations in shipping logistics industry, who is also a committee member of the advisory board of Hong Kong government in the logistics and shipping industry.

The duration of each interview was about one and a half hour in average. Note taking and audio recording were carried out to collect the views from the interviewees.

\section{Findings and Analysis}

\subsection{Interviewees}

As mentioned, five interviewees have been invited for interviews on their views towards corporate governance in logistics and shipping industry of Hong Kong. All of them are experienced practitioners in related field. The interviewees background are shown in table below (Table 1).

\section{Table 1: Interviewees Background}

\begin{tabular}{|c|c|}
\hline Interviewee & Background \\
\hline $\mathrm{A}$ & $\begin{array}{l}\text { He is a senior management of one of the listed companies in logistics and shipping industry in Hong Kong. } \\
\text { He has been working in operation and management of freight forwarding and logistics fields more than } 20 \text { years. } \\
\text { He has been elected as professional member \& executive member in various professional associations in Hong Kong. }\end{array}$ \\
\hline B & $\begin{array}{l}\text { - He is a senior management of one of the industry associations, who has more than } 20 \text { years of experience in shipping, freight forwarding, } \\
\text { mid-stream operations, and other transport and logistics services. } \\
\text { - He is an active member in various shipping and logistics committees of the Hong Kong Government and international professional bodies. }\end{array}$ \\
\hline $\mathrm{C}$ & $\begin{array}{l}\text { He is a middle management of one of the famous listed liner shipping companies in Hong Kong. } \\
\text { He has almost } 20 \text { years of experience in the industry. } \\
\text { - He is an active member in local industry association in shipping and logistics industry. }\end{array}$ \\
\hline $\mathrm{D}$ & $\begin{array}{l}\text { He is a senior management of one of the leading air services provider which is based on Hong Kong, which is also a listed company in Hong } \\
\text { Kong. } \\
\text { He has more than } 20 \text { years of experience in air transport industry. }\end{array}$ \\
\hline $\mathrm{E}$ & $\begin{array}{l}\text { He is a senior management of one of the well-known liner shipping company which is based on Hong Kong, which is also a listed company } \\
\text { in Hong Kong. } \\
\text { - He has more than } 20 \text { years of experience in shipping, marketing and corporate communication. }\end{array}$ \\
\hline
\end{tabular}




\subsection{Findings}

The major findings of interviews are listed in below.

\subsubsection{Rights of Shareholders}

Shareholders of company should have the rights to participate in, and be informed sufficiently on the decisions regarding fundamental corporate changes (OECD, 2004; Ko et al., 2016). Appointment of directors, objective of the shareholders' meeting agenda, and voting method are regarding as the right of shareholders (Ko et al., 2016).

Interviewees have been asked to provide views on shareholders in corporate governance. Interviewee A said that, the investors were more concern on the profit and benefit the company could make, rather than the practice of corporate governance. And small shareholders "seldom ask for details on corporate governance". While the strategic investors have already known the profitability of the company, so that they are "no big deal on corporate governance". They are "only challenge why loss or gain less".

Interviewee E responded that the company has devoted to work for the shareholders and different stakeholders of the company. Its commitment has been disclosed on the official website, annual and sustainability report. Interviewees $\mathrm{B}, \mathrm{C}$, and $\mathrm{D}$ have not explicitly responded to the issue of the rights of shareholders.

\subsubsection{Equitable Treatment of Shareholders}

Ko et al. (2016) mentioned that no company provided any mechanism to allow minority shareholders to influence the board composition. In the interviews with the interviewees, only interviewee A has mentioned minority shareholders. However, it is about they just concern the profitability, not the right to influence the board composition.

\subsubsection{Roles of Stakeholders}

\section{(A)Importance of stakeholder}

This study investigated if the companies value corporate social responsibility and their stakeholders. They found that companies valued most to their customers and shareholders by addressing them in the annual report in details. Seven stakeholders, namely customers, investors / shareholders, suppliers, employees, government, creditors, and community, have been listed in one of the interview questions. The interviewees have been asked to rank the importance of stakeholders to the company. Different interviewees have different ranking on the importance of stakeholders to the company.

As mentioned, interviewees have been asked to rank the order on the importance of stakeholders from the given seven parties. Below is the finding on their ranking. Government, customers, investors / shareholders and community are four major stakeholders in this study.

\section{(1) Government}

It is not surprising that Government has been ranked as the most importance of the stakeholders by three interviewees. Government as an important stakeholder, is because of the authority to require all the companies to comply with regulations and laws. Those fail to observe and comply with the regulations and laws, will be subjected to penalties or imprisonments, depending on the severity of the violation.

Besides, Government possesses the resources to shape the operating environment of the industry by formulating policies whether favourable or unfavourable to the development of a particular industry, perhaps by tightening or releasing certain requirements or regulations.

\section{(2) Customers}

Customers are ranked the second most importance of the stakeholders. It is obvious and undoubted that customers are essential to the survival of companies. Without their purchase of services or products, companies cannot receive revenue.

Customers' preference on whether the companies possess certain certifications, provide more discount price, or deliver high quality services, are factors which influence their buying decision. Customers have their own expectation on the companies. If companies do something out of customers' expectation, such as providing values to them, they will probably continuous to have the same companies as service providers. 


\section{(3) Investors / shareholders}

Investors / shareholders are essential for the development of companies, who are one of the major sources of finance. They provide financial resources for companies' operation and development. They have rights to withdraw their capital when they find that the plans and directions of the companies do not provide profitability, or make them lose even in short-term.

\section{(4) Community}

Community can be seen as broad or narrow definition from the companies. For broad view, community covers the whole Hong Kong. While from a narrow view, it is seen as locality or customer groups.

As suggested by interviewees, community can be seen as "the values of the Hong Kong society", or include other stakeholders such as customers and employees.

We summarize the interviewees' response on the ranking of the importance of stakeholders and list in table below (Table 2).

Table 2: Interviewees' response on the ranking of the importance of stakeholders Remarks: 1: Most Important; 7: most not important

\begin{tabular}{|l|l|l|l|l|l|}
\hline $\begin{array}{l}\text { Interviewee } \\
\text { Ranking } \\
\text { stakeholders }\end{array}$ & A & B & C & D & E \\
\hline 1 & Government & Government & Government & Customers & Customers \\
\hline 2 & Customers & Community & $\begin{array}{l}\text { Investors / } \\
\text { Shareholders }\end{array}$ & Employees & Community \\
\hline 3 & $\begin{array}{l}\text { Investors / } \\
\text { Shareholders }\end{array}$ & Customers & Customers & Community & Suppliers \\
\hline 4 & Creditors & Employees & Creditors & $\begin{array}{l}\text { Investors / } \\
\text { Shareholders }\end{array}$ & Employees \\
\hline 5 & Employees & $\begin{array}{l}\text { Investors / } \\
\text { Shareholders }\end{array}$ & Community & Government & Government \\
\hline 6 & Suppliers & Creditors & Suppliers & Suppliers & $\begin{array}{l}\text { Investors / } \\
\text { shareholders }\end{array}$ \\
\hline 7 & Community & Suppliers & Employees & Creditors & Creditors \\
\hline
\end{tabular}

(B) Obligation to the society

From Ko et al. (2016) study, they found that "obligations to the society" of the companies refer to charity work, such as donation or voluntary services organized by the company.

Interviewees have expressed views and situations which their companies have done. Interviewee A mentioned that staff of his company involved in voluntary service. The company would provide sponsorship to the staff to be volunteers, to increase their motivation such as time off and other benefits.

Interviewee $\mathrm{C}$ told that the holding limited company of his company would coordinate community and voluntary services. Volunteer teams have been set up and visited elderly homes, while some of the visits were carried out in Mainland China. In the Mainland, some voluntary services are arranged by the local government, where firms sponsor a poor county by both money and human resources. Company staff is assigned to be voluntary teachers at the poor county. Interviewee D mentioned a community programme, which cooperates with primary and secondary schools in Tung Chung. Volunteer team has 30-40 volunteers who are flight attendants, captains, engineers, and back office staff. The schools which joined the programme will send their students to the company, and the volunteers will teach and talk English related to aviation, including mock interviews. The programme has been conducting in few years, and about thousands of students have joined.

Interviewee E responded that if possible, the company will invite its customers and investors to participate in the CSR events, "revealing our commitment to the community". Moreover, if employee "proactively contributes the betterment of our community through active participation in public service initiatives, he or she will be awarded with charity credit. In addition, an Honorary Award will be presented to the colleague who gets the highest charity credits in a year".

\section{(C) Corporate Citizenship}

The study have investigated "corporate citizenship" in the performance of the roles of stakeholders. They found that companies have very weak sense of identity as corporate citizens. As there are no guidelines in the CG Code to tell companies how to perform duties as a corporate citizen. 
In the interviews, interviewees were also asked on their views on corporate citizenship. Interviewee B expressed that the concept of corporate citizenship has not well promoted and recognized in Hong Kong. This is because the industry operating environment is difficult in Hong Kong, which affects companies' investment in corporate social responsibility, hence corporate citizenship.

When talking about corporate citizenship, interviewee $\mathrm{C}$ mentioned the example of Starbuck on fair trade, which promotes local and worldwide value. In addition, he responded an example from the company he works for in order to illustrate corporate citizenship. The company carried out renovation work for local office, and requested the provider of renovation service to use environmental-friendly materials, in which they were produced and processed environmental-friendly. The use of such materials is responsible to the nature and health of employees.

Interviewee D expressed that corporate citizenship referred as "Hong Kong brand and positioning". The company offers package to Hong Kong residents, such as special fares for Hong Kong students who study abroad, and bundle tickets for Hong Kong customers and local senior citizens regularly.

Interviewee E referred corporate citizenship as "embraces the core values including 'Community Responsibility' and is dedicated to contribute back to society", and "dedication to environmental protection and community investment, supported and driven by the company's core values, as a responsible corporate citizen".

\subsubsection{Disclosure and Transparency}

In Ko et al. (2016) study, whether companies are willing to communicate with their stakeholders is the focus of the performance of disclosure and transparency. Channels for accessing company's information are essential.

The annual reports and company's websites of the interviewees who work for are accessible. Interviewee A added that CSR report also included in the annual report. While interviewee $\mathrm{C}$ and $\mathrm{E}$ told that annual report contained CSR issue, but individual CSR report also prepared separately.

\subsubsection{Board Responsibilities}

Ko et al. (2016) focused on four major aspects in board responsibilities, namely code of conduct, quality of subcommittee report, training of directors, and independency of the board. Items emphasized including whether the company provided a code of ethics or statement of business conduct for all directors and employees, internal audit issues and so on. Interviewee A mentioned that environmental conservation, training on occupational safety to staff was provided. And independent department focuses on internal control and compliance matters.

Interviewee $\mathrm{C}$ responded that safety committees have been set up for each unit in the company, in order to manage internal production and operation, container ports. There is a safety committee in the office, carries out regular check for any potential dangers, which aims for protecting employees and building premises.

Interviewee E mentioned that company has a strong culture to put priority on safety, security and environment. Regular training and drills are scheduled for employees to understand the company's concept of management. An online platform is provided for employees to familiarize themselves with corporate policy and standard. SSE (Safety, Security \& Environment) committee is responsible for the implementation of the workplace code to capture incident trends and lessons learnt so that the company can prevent the same from happening in other regions and in the future.

\section{Implications and Conclusion}

The findings show that the companies in the shipping and logistics industry of Hong Kong tend to meet the minimum requirements set by the CG code. This matches with the result suggested by the study of Ko et al. (2016). Rooms for improvement in corporate governance in the companies of the industry have much space. As proposed by Interviewee B, education on the positive benefits and industry recognition for corporate governance and corporate social responsibilities are important for promotion and implementation.

The finding on the importance of stakeholders to the company provided a significant insight. Government plays an essential role in promoting and implementing corporate governance of the companies in the shipping and logistics industry. Incentives such as tax allowance are better provided so that companies in the industry are motivated to implement corporate governance and corporate social responsibilities. 
Since the industry tends to comply with regulations and laws in the minimum requirements, it is suggested that Government can consider increasing the basic requirements on corporate governance in the shipping and logistics industry, in order to push the CG in "higher level". At the same time, government can also encourage and recognize the effort for those companies which practice $\mathrm{CG}$, such as provision of discount on annual business registration fee, or even profit tax.

Another issue is corporate citizenship, which is a relative new concept. This concept can be better promoted in the industry. Few steps can be adopted to let the industry understand that corporate citizenship may help companies' image and brand building, in return attract more business opportunities. First, promoting good practices by successful cases from the leading companies in the industry as role model, so that other companies within the industry have a benchmark to follow. Second, successful leading companies share their experience through seminars, sending experts to industry or professional associations for sharing. Third, the industry or professional associations, as a sharing and supporting platform, to help companies in the industry to practice the concept with the aspects in marketing, human resources, etc. When they find that corporate citizenship is not difficult to implement, and eventually may bring benefits to them, they are willing to put effort on it.

Undoubtedly, corporate governance is becoming more important to our business operation, investment profession as well as community. The governance practices in the logistics and shipping industry kept improving over the last-decade, however, the results of our investigation shows that companies tend to barely meet the minimum requirements set by the CG Code, only a few of them are willing to promote good governance voluntarily.

The major limitation of this study is there is only focus on shipping logistics industry with five interviewees. An empirical analysis and case studies are recommended to conduct research in next stage. Moreover, further research is needed to compare the governance level of the logistics and shipping industry with the other key industries, such as banking \& finance, and tourism. Also, it is recommended to demonstrate the case study, as "role model" of CG \& CSR practice in our industry for benchmarking.

\section{References}

Andreou, P.C., Louca, C., \& Panayides, P.M. (2014). Corporate governance, financial management decisions and firm performance: Evidence from the maritime industry. Transportation Research Part E, 63, 59-78.

Bhagat, S., \& Black, B. (2002).The non-correlation between board independence and long-term firm performance.Journal of Corporation Law, 27, 231-273.

Bryman, A., \& Bell, E. (2015).Business Research Methods, UK: Oxford University Press.

Chen, J.P., \&Jaggi, B. (2000).Association between independent non-executive directors, family control and financial disclosures in Hong Kong.Journal of Accounting and Public Policy, 19, 285-310.

Cheung, S. (2012). Report on the HKIoD Corporate Governance Score-card, The Hong Kong Institute of Directors.

Cooper, D.R. \& Schindler, P.S. (2003).Business Research Methods, McGraw Hill.

Daines, R.M., Gow, I.D., \&Larcker, D.F. (2010). Rating the ratings: how good are commercial governance ratings?.Journal of Financial Economics, 98, 439-461.

Eriksson, P., \&Kovalainen, A. (2016).Qualitative Methods in Business Research: A Practical Guide to Social Research. London: SAGE Publications Ltd.

Firth, M., Fung, P.M.Y., \&Rui, O.M. (2007). How ownership and corporate governance influence chief executive pay in China's listed firms. Journal of Business Research, 60, 776-785.

Giannakopoulou E.N., Thalassinos E.I. and Stamatopoulos T.V. (2016). Corporate governance in shipping: an overview. Maritime Policy and Management, 43(1), 19-38.

Gompers, P., Ishii, J., \&Metrick, A. (2003).Corporate governance and equity prices.Quarterly Journal of Economics, 118, 107-155.

Grammenos, C.T., \&Papapostolou, N.C. (2012). US shipping initial public offerings: do prospectus and market information matter?.Transportation Research Part E, 48(1), 276-295.

Hermalin, B., \&Weisbach, M. (1991).The effects of board composition and direct incentives on firm performance.Financial Management, 20, 101-112.

Institutional Shareholder Services (2003).ISS Corporate Governance: Best Practices User Guide \& Glossary, Revision 2.4, October 8, 2003. 
Karuna, C. (2007). Industry product market competition and managerial incentives.Journal of Accounting and Economics, 43, 275-297.

Ko, H.C.A., \& Chan, S.Y.R. (2014). How ownership structures affect the relations between product market competition, and pay-performance sensitivity. Journal of Accounting Finance and Economics, 4(1), 5367.

Ko, H.C.A., \& So, H.H.S. (2012). How does corporate governance affect CEO pay in family and non-family firms?.Global Review of Accounting and Finance, 3, 18-31.

Ko, H.C.A., Yuen, S.M.S., \& Yung, K.M.A. (2016). Corporate governance practices in logistics and shipping industry. Journal of Business and Policy Research, 11(2), 123-140.

Koufopoulos, D.N., Lagoudis, I.N., Theotokas, I.N., and Syriopoulos, T.C. (2010).Corporate governance and board practices by Greek shipping management companies.Corporate Governance, 10(3), 261-278.

La Porta, R., Lopez-de-Silanes, F., Schleifer, A., \&Vishny, R. (1998). Law and finance.Journal of Political Economy, 106, 1113-1155.

Lee, C., Rosenstein, S., Rangan, N., \& Davidson, W. (1992). Board composition and shareholder wealth: the case of management buyouts. Financial Management, 21, 58-73.

Leung, S., \& Horwitz, B. (2004). Director ownership and voluntary segment disclosure: Hong Kong Evidence. Journal of International Financial Management \& Accounting, 15, 235-260.

Mangan, J., Lalwani, C. \& Gardner, B. (2004).Combining quantitative and qualitative methodologies in logistics research.International Journal of Physical Distribution \& Logistics Management, 34, 565-578.

McConnell, J., \&Servaes, H. (1990).Additional evidence on equity ownership and corporate value.Journal of Financial Economics, 27, 595-612.

Miles, M.B. \& Huberman, A.M. (1994).Qualitative data analysis: An expanded sourcebook, Sage Publications.

Morck, R., Shleifer, A., \&Vishny, R. (1988). Management ownership and market valuation: an empirical analysis. Journal of Financial Economics, 20, 293-315.

Myers, M.D. (2013). Qualitative Research in Business and Management, London: SAGE Publications Ltd.

Naslund, D. (2002). Logistics needs qualitative research: especially action research. International Journal of Physical Distribution \& Logistics Management, 32, 321-338.

OECD (2004).Principles of Corporate Governance, Organization of Economic Co-operation and Development.

Randoy, T., Down, J., \&Jenssen, J. (2003). Corporate governance and board effectiveness in maritime firms.Journal of Maritime Economics and Logistics, 5, 23-39.

Song, D.W., \& Panayides, P.M. (2012).Maritime logistics: a complete guide to effective shipping and port management, Kogan Page, London.

Syriopoulos, T., \&Theotokas, I. (2007).Value creation through corporate destruction?Corporate governance in shipping takeovers.Maritime Policy Management, 34(3), 225-242.

Syriopoulos, T., \&Tsatsaronis, M. (2011). The corporate governance model of the shipping firms: financial performance implications. Maritime Policy Management, 38(6), 585-604.

Tsionas, M., Merikas A., \&Merika A. (2012). Concentrated ownership and corporate performance revisited: The case of shipping. Transportation Research Part E: Logistics and Transportation Review, 48, 843-852.

Tuan, L.T. (2013). What can corporate governance build in shipping companies?.International Journal of Shipping and Transport Logistics, 5(2), 113-136.

Wei, Z.T. (2017, February 21), Hanjin Shipping: Rest In Peace. Lloyd's List. Retrieved from https://www.lloydslist.com/ll/sector/containers/article550212.ece

Yermack, D. (1996). Higher market valuation of companies with a small board of directors. Journal of Financial Economics, 40, 185-211. 